American Journal of Applied Sciences 7 (4): 597-602, 2010

ISSN 1546-9239

(C) 2010Science Publications

\title{
Determination and Evaluation of Privatization Effects on Financial Performance of Firms in Tehran Stock Exchange (TSE)
}

\author{
${ }^{1}$ Hossein Panahian and ${ }^{2}$ Hamid Akbarzadeh \\ ${ }^{1}$ Azad University, Kashan Branch, Kashan, Iran \\ ${ }^{2}$ NIOPDC, Kashani St., Yazd, Iran
}

\begin{abstract}
Problem statement: Does privatization process, as form of transferring the control of public (state-owned) companies via Tehran Stock Exchange, effect positively on their financial performance? In this study privatized and public firms were compared during 3 years before and after privatization process from 1994 -2007. Approach: To achieve the purpose of the study, the pre-test and post-test design was used. It included two experimental groups and one control group. Results: The results of comparing performance before and after privatization in these firms indicated significant relationship between privatization process and financial performance indices debt-asset ratio, return on total asset, return on equity, return on sale, operating income-sale ratio, gross profit margin, earning per share. Besides, comparing the performance of privatized and public companies showed a significant difference only in EPS $(\mathrm{p}=0.026)$, while there is no significant relationship between privatization and other variables. Conclusion: These results indicated that by passing the transformation stage in the type of ownership in companies, privatized companies have more significance increase in the index EPS in comparison with government companies.
\end{abstract}

Key words: Privatization, public (government) firms, privatized firms

\section{INTRODUCTION}

Although classic theory stresses consistently on restricting government intervention in economic affairs, great Economic Crisis in late 1920s in industrial countries and their relatively slow movements for coping with the crisis, the effects of socialistic revolution, Second World War and reconstruction thereafter raised much doubt about classic theory and highlighted justifiable motives for government intervention in economic affairs to adopt Keynes theory (Komijani, 1999). During 1950s and 1960s, industrial countries experienced a consistent era together with reasonable economic growth and government's active role via government entities, which resulted in relative success; meanwhile little attention was paid to limited criticism on the government intervention in the economy. In 1970s, the operation of previous policy was continued strictly, but the attempts to boost the economy did not succeed, until economy was suffering from recession and went through a lean time. Theoretical disputes in scientific assembly made it serious to review the extent of government intervention in economy and classic theories took precedence over other rival ones. In early 1980s, appearance of privatization and restriction of government intervention in order to obviate economic problems was at the top of the agenda in England and then industrial countries (Prescott, 1998; Brown et al., 2004). In addition, in developing countries, abandoning dominant policies of government led to government motive to restrict its intervention and create sufficient opportunity for private sector (Weizsacker et al., 1997; Megginson et al., 2003). So, privatization policy has been considered as one of the most important economy-adjusting policies from mid 1980 s so far.

Definitions and concepts of privatization: "Privatization", like most political concepts, has many similar concepts. In the most common concept, this term refers to all initiatives designed to increase the role of private entities for applying society resources to produce products and services by decreasing and restricting government or official's roles (Heydari Kord Zanganeh, 2001). In Merriam -Webster Dictionary, the word "privatization" is defined as "to transform something from state control or ownership to private ownership" $(1983,524)$. Privatization is the process in which market mechanism and Adam Smith's theory, Invisible Hand, are again going strong, assessment of government's actions is criticized and thus public sector (government) decides to limit the range of its action and 
to transform "ownership or management" of some economic entities from state control or ownership to market mechanism (Che, 2007). Perhaps, in a comprehensive sense, privatization can be defined as a kind of market-oriented process, moving toward adjusting the role of government and market in economic actions and obviating government monopoly, particularly or generally, over parts of national economy.

The history of privatization in Iran: In Iran, the boundary between private and public ownership is determined in Public Audit Act and definition of public companies. According to the contents of forth article of Public Audit Act, approved in 1987, public firm either is a determined institutional entity which is established legally as a firm or it has been nationalized or sequestrated by law or national competent court and recognized as a public firm and the government has more than $50 \%$ of its possession. Any commercial firms established through public firm investment are considered as public or government companies as far as the government has more than $50 \%$ of its possession. So, in Iran, privatization equals transferring public stocks so that government's share in these companies decline to less than $50 \%$ causing transferring their state management to private sector. In our country, synchronized with the first five-year development plan (considerably note 32 in this law), privatization policy has been approved as one of the possible solutions for restricting government intervention in economy and involvement of private sector in economic affairs then privatization organization was established according to article 15 of third development plan, approved in 2000. Later, privatization organization was founded on the strength of Article 15 of development plan (enacted 2000) by amending articles of association of former "financial organization for development of ownership of manufacturing units" (founded in 1975 by virtue of Sub-article 4 of single article for development of ownership of manufacturing units). The newly set up organization followed the way of privatization according to provisions of development plan.

Statement of the problem and significance of the study: For several decades, one of the most critical problems economists have faced has been global movement for privatization, expansion of private sector and decrease in the government control in order to boost economy and to set government free from administration of entities which private sector is willing and able to administer (Kikeri and Nellis, 1999). Global perspective on agreements for free trade and international bodies, like World Bank, World Trade Organization, International Monetary Fund Organization for Economic Co-operation and Development are moving towards reforming economic structures as form of Case-by-Case approach to privatization (Welch and Fremond, 2001; Kikeri and Kolo, 2005). Using real-world evidence, the present study examines the methods of privatization and some of the conditions causing the success of countries in operating this policy. It particularly analyses the effects of privatization on financial performance of Iranian companies. Regarding Supreme Leader's proclaim of general policies for article 44 of Islamic Republic Constitution, the present tendency in Iran to reform economic structure, especially in privatization framework, along with applying the experiences of other successful countries can be of high importance for economic planners to cope with future challenges in the process. Considering above mentioned points, the main question in this study is:

Does privatization process, as form of transferring the control of public (state-owned) companies via Tehran Stock Exchange, effect positively on their financial performance?

\section{MATERIALS AND METHODS}

In this study a pre-test and post-test design was used. In order to determine and assess the effects of privatization on financial performance of companies, the study used two experimental groups and a control group during two periods, 3 years before and after privatization. The design was used due to the fact that the independent variable (privatization) had already been occurred and also due to the method of sampling (systematic).

Research hypotheses: The present study intends to examine the relationship between independent variable (privatization process) and dependent variables (financial performance of companies) using seven financial indices. To achieve the purpose of the study, two sets of hypotheses are formulated to assess relation above.

Major hypotheses: There is a significant relationship between privatization process and average Debit-Asset ratio (D/A), Return On Assets (ROA), Return On Equity (ROE), Return On Sales (ROS), operating profit-sale ratio (ROP), gross profit margin (ROG), Earning Per Share (EPS) for privatized companies in Tehran Stock Exchange. 
Am. J. Applied Sci., 7 (4): 597-602, 2010

Table 1: One-sample Kolmogorov-Smirnov test

\begin{tabular}{|c|c|c|c|c|c|c|c|c|c|c|c|c|c|c|}
\hline & DA_a & DA_b & ROA_a & ROA_b & ROE_a & ROE_b & ROS_a & ROS_b & ROP $\_a$ & ROP_b & ROG_a & ROG_b & EPS_a & EPS_b \\
\hline $\mathrm{N}$ & 87.00 & 87.00 & 87.00 & 87.00 & 87.00 & 87.00 & 87.00 & 87.00 & 87.00 & 87.00 & 87.00 & 87.00 & 87.00 & 87.00 \\
\hline \multicolumn{15}{|c|}{ Normal a, b parameters } \\
\hline Mean & 87.02 & 75.87 & 5.62 & 12.89 & 61.05 & 137.22 & -24.81 & 2.09 & -5.05 & 13.54 & 11.38 & 25.04 & 3851.01 & 1825.15 \\
\hline SD & 42.98 & 17.19 & 21.60 & 14.47 & 113.25 & 161.70 & 201.97 & 124.96 & 107.09 & 36.07 & 75.87 & 17.35 & 12614.1 & 3420.80 \\
\hline \multicolumn{15}{|c|}{ Most extreme differences } \\
\hline Absolute & 0.27 & 0.13 & 10.00 & 0.08 & 0.07 & 0.15 & 0.39 & 0.38 & 0.30 & 0.22 & 0.31 & 0.08 & 0.31 & 0.24 \\
\hline Positive & 0.27 & 0.13 & 0.08 & 0.05 & 0.07 & 0.15 & 0.33 & 0.32 & 0.29 & 0.19 & 0.27 & 0.07 & 0.31 & 0.24 \\
\hline Negative & -0.19 & -.05 & -0.10 & -.08 & -.05 & -.10 & -.39 & -.38 & -.30 & -.22 & -.31 & -.08 & -.24 & -.19 \\
\hline $\begin{array}{l}\text { Kolmogorov- } \\
\text { Smirnov Z }\end{array}$ & 2.48 & 1.21 & 0.95 & 0.72 & 0.66 & 1.39 & 3.63 & 3.51 & 2.82 & 2.04 & 2.88 & 0.77 & 2.92 & 2.22 \\
\hline $\begin{array}{l}\text { Asymp. Sig. } \\
\text { (2-tailed) }\end{array}$ & 0.000 & 0.107 & 0.326 & 0.682 & 0.769 & 0.041 & 0.000 & 0.000 & 0.000 & 0.001 & 0.000 & 0.591 & 0.000 & 0.000 \\
\hline
\end{tabular}

a: after privatization; $b$ : before privatization

Minor hypotheses: There is significant relationship between average Debit-Asset ratio (D/A), Return On Assets(ROA), Return On Equity (ROE), Return On Sales (ROS), operating profit-sale ratio (ROP), gross profit margin (ROG), Earning Per Share (EPS) for privatized companies in Tehran Stock Exchange during a matched period with government companies of the same industry in Tehran Security Stock.

Statistical methods to test hypotheses: Table 1 shows the results of Kolmogorov-Smirnov Test, a method to test normal distribution, for all variables.

In the present study, regarding abnormality of data (normality of five modes out of seven), nonparametric tests have been used.

So, two matched samples the Wilcoxon signed rank test and Mann-Whiteny Test have been used to test major and minor hypotheses, respectively.

\section{Wilcoxon signed rank test:}

Two matched samples: The first part of the research hypotheses (major ones) compares seven financial indices before and after privatization in privatized companies in Tehran Stock Exchange. Therefore, its statistical hypotheses, $\mathrm{H}_{0}$ and $\mathrm{H}_{1}$, are as follows:

\section{Test 1:}

$$
\begin{aligned}
& \mathrm{H}_{0}: \mu_{1}-\mu_{2} \leq 0 \\
& \mathrm{H}_{1}: \mu_{1}-\mu_{2}>0
\end{aligned}
$$

Where:

$\mu_{1}=$ Index mean after privatization process

$\mu_{2}=$ Index mean before privatization process

$\mathrm{H}_{0}=$ Index mean after privatization process in privatized companies is less than before (Privatization process does not effect positively on financial performance in privatized companies
$\mathrm{H}_{1}=$ Index mean after privatization process in privatized companies is more than before (Privatization process effects positively on financial performance in privatized companies)

Mann-Whitney test: The second part of research design (minor hypotheses) compares seven financial performance indices before and after privatization process in privatized companies during a period matched with government companies in same industry in Tehran Stock Exchange. The purpose of designing and testing these control hypotheses was to ensure the reliability and internal validity of the research as much as possible via eliminating the effects of environmental factors. Accordingly, $\mathrm{H}_{0}$ and $\mathrm{H}_{1}$ are formulated as follows:

\section{Test 2:}

$\mathrm{H}_{0}=$ Mean difference in privatized companies is less than government companies

$\mathrm{H}_{1}=$ Mean difference in privatized companies is more than government companies

Statistical population: Statistical population is a set of samples having one or more common specifications. All privatized companies in Tehran Stock Exchange, which are subject to transferring to private sector after approving and enacting the law of transferring stateowned companies in 1990 (transferring more than 50\% of state-owned companies to private sector according to the Public Audit Act), together with all state-owned companies in the same industry accepted in Tehran Stock Exchange, are the statistical population of the study.

In this study, sample selection is based on judgment method (Arkin, 2001). Finally, 59 privatized companies together with 28 government companies in Tehran Stock Exchange were selected as samples in 20 groups from various industries. 


\section{RESULTS AND DISCUSSION}

Regarding statistical test of major hypothesis and the results of Table 2 in Wilcoxon signed rank test for privatized companies, it can be expressed that the results of this test suggest significant differences before and after privatization for all financial indices (D/A, ROA, ROE, ROS, ROP, ROG, EPS); in analyzing and expressing $\mathrm{H}_{0}$, which suggests financial indices mean for privatized companies after privatization process has been less than before this process, the $\mathrm{H}_{0}$ was significant only for D/A and EPS at 0.05 level. $\left(\mathrm{H}_{0}\right.$ is rejected as far as these two variables are concerned, while it was accepted for other variables.

Also it should be noted that among these seven financial indices, only D/A and EPS had higher amounts in next year after privatization for Table 3 in Wilcoxon signed rank test in privatized companies.

Comparing the results of Table 5 in Wilcoxon signed rank test for government companies with those of Table 4 for privatized companies, given that the difference between pre and post stages of privatization were significant, it is clear that variables D/A, ROS, ROP, ROG, EPS do not show significant difference for stages before and after privatization process, but the significant difference was observed only for ROA and ROE in government companies. In contrast, the difference was significant for privatized companies. The following points are clear in a more accurate analysis.

Variable EPS, showing more negative ranks than positive ones for privatized companies, have shown more positive ranks for government companies. In other words, EPS in next year after privatization was higher than the year before privatization for privatized companies, whereas this variable in next year after privatization was less than the year before privatization for government companies. Even in the case of ROE and ROA showing significant difference for government companies, significance differs as compared with the test for privatized companies.

Table 2: List of privatized and government companies from various in stock exchange industries

\begin{tabular}{|c|c|c|}
\hline Category & Privatized & Governmental \\
\hline Exploitation of metalore & Mines of Bafgh-1999 & \\
\hline Exploitation other mines & Spool making-1999; Supply sand casting 1999 & \\
\hline Textile & $\begin{array}{l}\text { Azadi texture-1997; Industrial group } \\
\text { of Naghs-e Iran-1998 Khoy Textile Factory-2004 }\end{array}$ & $\begin{array}{l}\text { Mazandaran Textile; Ghaemshahr Textile; Gharb Textile; } \\
\text { Kashan Valvet and Silk Factory; Babkan Textile; Iran Povilin }\end{array}$ \\
\hline Paper products & $\begin{array}{l}\text { Alborz Carton-2000; Pars Carton-2005; } \\
\text { Pars Packaging Company-2005; Offset-2002 }\end{array}$ & \\
\hline Tire and plastic & Iran Tire-1997 & \\
\hline Basic metals & Ahwaz Rolling and Pipe Mills-2004 & Iran Aluminum Company \\
\hline Production of metal products & Azarab-2003; Avangan-2004; Paysaz-2005 & Malayer Industrial-Machine Sazi Arak \\
\hline Machinery and euipment & $\begin{array}{l}\text { Pars Pomp-2007; Pars Appliance-1999; } \\
\text { Azmayesh-2002; Lorestan Refrigerator bearing Co. } \\
\text { Manufacturing Company-2003; Iran } \\
\text { Tractor Manufacturing Company -2004; } \\
\text { Iran Combine Inc.-2004 }\end{array}$ & Compressor Manufacturing Co.-Hepco, Iran Ball \\
\hline Electrical machinery and apparatus & Tak Cable Manutacturing Co.-2002 & Iran Transfo Co. \\
\hline $\begin{array}{l}\text { Radio and television and electronic } \\
\text { appliance manufacturer }\end{array}$ & Pars Electric-2009; Jahan Nama - 2000 & \\
\hline Automobile and automobile & $\begin{array}{l}\text { Iran Khodro-1999; Iran Khodro Diesel 1999; } \\
\text { part manufacturer Saipa Diesel-1999; Mehvarsazan-1999; } \\
\text { Iran Radiator -1999; Zar Spring Manufacturing } \\
\text { Co.-1999; Khavar Spring Manufacturing Co.-1999; Iran } \\
\text { Automobile Parts-1999; Saipa-2000; Pars Khodro-2000; } \\
\text { Zamyad -2000; Rena Industrial-2000; INDAMIN Shock } \\
\text { Absorber Manufacturing Co.-2000; Charkheshgar-2001; } \\
\text { Iran Tractor Forging Co.-2002; Iran Tractor Motorsazan,- } \\
\text { 2005; Iran Tractor Foundry Co.-2005; }\end{array}$ & \\
\hline Sugar and sugar cane & $\begin{array}{l}\text { Piranshahr Sugar Co.-1997; Neyshaboor Sugar Co.-2000; } \\
\text { Pars Sugar Co.-2006 }\end{array}$ & \\
\hline Food and drink products & Pars Minoo-1997; Vitana-2000; Minoo & $\begin{array}{l}\text { National Cultivation and Industry; Industrial-2002 } \\
\text { Tejarat Flour; Jahan Oil Co.; Shahd Ab; Mashhad Food } \\
\text { Industrial }\end{array}$ \\
\hline Medicinal material and products & Amin Pharmaceutical Co.-1997 & $\begin{array}{l}\text { Jaber Ibn Hayyan; Sina Pharmaceutical; Osweh } \\
\text { Pharmaceutical Co. }\end{array}$ \\
\hline Chemical products & Aliaf Co-1997; Synthetic Fiber Raw & $\begin{array}{l}\text { Iran Chemical Industrial, Arak Niroo Material } \\
\text { Manufacturing Co. - 2004; Chlorine Petrochemical }\end{array}$ \\
\hline Industrial subcontracting & Iran Marine Industrial-2003 & \\
\hline Tile and ceramic & Isfahan Tile-2002; Saadi Tile-2003 & \\
\hline Other non - metal ore products & Aytalyran-1997; Alborz Porcelain-2002 & \\
\hline Cement, lime and plaster & Hegmatan Cement-2002; Sepahan & $\begin{array}{l}\text { Darab Cement-Hormozgan Cement 2002; } \\
\text { Khash Cement 2003; Ardebil Cement 2003; and Azar } \\
\text { Shahr Plaster } 2004\end{array}$ \\
\hline
\end{tabular}


To put it differently, significance level was higher in government companies and this shows that indices ROA and ROE are preferred in order to separate the stages before and after privatization process in privatized companies, while no changes were observed in other indices in this respect.

In concluding statistical test, conducted for minor hypotheses and the results of Table 6 in Mann- Whitney test, it can be said that indices (D/A, ROA, ROE, ROS, ROP, ROG) did not show significant difference between privatized and government companies in terms of difference, considering the results of this test suggesting insignificant differences for financial indices before and after privatization process between privatized and government companies, only EPS showed significant difference between government and privatized companies in terms of mean difference of financial indices.

Therefore, $\mathrm{H}_{0}$ suggesting mean differences of financial indices in privatized companies are less than government ones, is significant only for EPS at 0.05 level $\left(\mathrm{H}_{0}\right.$ is rejected as far as EPS is concerned). clear:

In detailed analysis, the following findings are

In the case of EPS, considering its significance $(p=0.026)$, the hypothesis suggesting there is a difference in privatized and government companies in terms of this index, was accepted. This shows that EPS has met the standards for separating the type of company and predicting future status in terms of being private or public as compared with other variables. Furthermore, it is clear from Table 4 that total rank for EPS-DIF (difference $=$ pre and post privatization) are 2841 and 987 in privatized and government companies, respectively.

Table 3: Ranked statistics of Wilcoxon signed rank test for privatized companies

\begin{tabular}{|c|c|c|c|}
\hline & $\mathrm{N}$ & Mean rank & Sum of rank \\
\hline \multicolumn{4}{|l|}{ DA_b-DA_a } \\
\hline Negative rank & 35 & 33.89 & 1186.00 \\
\hline Positive rank & 24 & 24.33 & 584.00 \\
\hline Ties & 0 & & \\
\hline Total & 59 & & \\
\hline \multicolumn{4}{|l|}{ ROA_b-ROA_a } \\
\hline Negative rank & 17 & 23.29 & 396.00 \\
\hline Positive rank & 42 & 32.71 & 1374.00 \\
\hline Ties & 0 & & \\
\hline Total & 59 & & \\
\hline \multicolumn{4}{|l|}{ ROE_b-ROE_a } \\
\hline Negative rank & 13 & 23.38 & 304.00 \\
\hline Positive rank & 46 & 31.87 & 1466.00 \\
\hline Ties & 0 & & \\
\hline Total & 59 & & \\
\hline \multicolumn{4}{|l|}{ ROS_b-ROS_a } \\
\hline Negative rank & 18 & 23.44 & 422.00 \\
\hline Positive rank & 41 & 32.88 & 1348.00 \\
\hline Ties & 0 & & \\
\hline Total & 59 & & \\
\hline \multicolumn{4}{|l|}{ ROP_b-ROP_a } \\
\hline Negative rank & 17 & 25.71 & 437.00 \\
\hline Positive rank & 42 & 31.74 & 1333.00 \\
\hline Ties & 0 & & \\
\hline Total & 59 & & \\
\hline \multicolumn{4}{|l|}{ ROG_b-ROG_a } \\
\hline Negative rank & 17 & 24.56 & 417.50 \\
\hline Positive rank & 41 & 31.55 & 1293.50 \\
\hline Ties & 1 & & \\
\hline Total & 59 & & \\
\hline \multicolumn{4}{|l|}{ EPS_B-EPS_a } \\
\hline Negative rank & 36 & 33.56 & 1208.00 \\
\hline Positive rank & 23 & 24.43 & 562.00 \\
\hline Ties & 0 & & \\
\hline Total & 59 & & \\
\hline
\end{tabular}

Table 4: Wilcoxon signed rank test for difference of pre-stage from post-stage of privatization in privatized companies

\begin{tabular}{|c|c|c|c|c|c|c|c|}
\hline & DA_b-DA_a & ROA_b-ROA_a & ROE_b-ROE_a & ROS_b-ROS_a & ROP_b-ROP_a & ROG_b-ROG_a & EPS_b-EPS_a \\
\hline $\mathrm{Z}$ & $-2.272^{\mathrm{a}}$ & $-3.691^{b}$ & $-4.385^{\mathrm{b}}$ & $-3.495^{\mathrm{b}}$ & $-3.382^{\mathrm{b}}$ & $-3.391^{b}$ & $-2.438^{\mathrm{a}}$ \\
\hline Asymp. Sig. (2-tailed) & 0.023 & 0.000 & 0.000 & 0.000 & 0.001 & 0.001 & 0.015 \\
\hline
\end{tabular}

a: after privatization; $b$ : before privatization

Table 5: Wilcoxon signed rank test for difference of pre-stage from post-stage of privatization in government companies

\begin{tabular}{|c|c|c|c|c|c|c|}
\hline & DA_b-DA_a & ROA_b-ROA_a & ROE_b-ROE_a & ROS_b-ROS_a & ROG_b-ROG_a & EPS_b-EPS_a \\
\hline $\mathrm{Z}$ & $-1.822^{\mathrm{a}}$ & $-2.710^{\mathrm{b}}$ & $-2.482^{\mathrm{b}}$ & $-1.435^{\mathrm{b}}$ & $-1.298^{\mathrm{b}} \quad-1.765^{\mathrm{b}}$ & $-820^{\mathrm{a}}$ \\
\hline Asymp. Sig. (2-tailed) & 0.068 & 0.007 & 0.013 & 0.151 & 0.194 & 0.412 \\
\hline
\end{tabular}

a: after privatization; b: before privatization

Table 6: Mann-Whitney test for comparison of privatized companies with government ones in terms of difference of means for pre and postprivatization

\begin{tabular}{lllllll}
\hline & DA_DIF & ROA_DIF & ROE_DIF & ROS_DIF & ROP_DIF & ROG_DIF \\
\hline Mann-Whitney U & 825.000 & 785.000 & 711.000 & 763.000 & 773.000 & 761.000 \\
Wilcoxon W & 2595.000 & 1191.00 & 2481.000 & 1169.000 & 1179.500 & 1167.000 \\
Z & -0.009 & -0.373 & -1.045 & -0.572 & -0.477 & -0.591 \\
Asymp. Sig. (2-tailed) & 0.993 & 0.710 & 0.296 & 0.567 & 0.633 & 0.555 \\
\hline
\end{tabular}

DIF: Difference of means for pre and post-privatization 


\section{CONCLUSION}

This shows that by passing the transformation stage in the type of ownership in companies, privatized companies have had more significance increase in the index EPS in comparison with government companies.

\section{REFERENCES}

Arkin, H., 2001. Sampling for Auditing and Accounting. Princeton University Press, Princeton.

Brown, J.D., J.S. Earle and A. Telegdy, 2004. Does privatization raise productivity? Evidence from comprehensive panel data on manufacturing firms in Hungary, Romania, Russia, Ukraine. Econ Papers.

http://econpapers.repec.org/paper/upjweupjo/04107.htm

Heydari Kord Zanganeh, G.R., 2001. Designing privatization model in Iran. Payame Iran Khodro, 17: 78-43.

Che, J., 2007. A dynamic model of privatization with endogenous post-privatization performance. Rev. Econ. Studies, 76: 563-596, DOI: 10.1111/j.1467937X.2009.00533.x
Kikeri, S. and A.F. Kolo, 2005. Privatization: Trends and recent developments. J. Financ. Econ., 69: 5-50.

Kikeri, S. and J. Nellis, 1999. Privatization in competitive sectors: The records so far. Quarterly J. Econ., 114: 83-116.

Komijani, A., 1999. The Assessment of Performance of Privatization Policy in Iran, Ministry of Economy and Finance, Vice president of Economic Affairs.

Megginson, W., F. Michael and M. Boutchkova, 2003. The Impact of privatization on capital market development and individual share ownership. Econ. Let., 65: 131-134.

Prescott, E.C., 1998. Needed: A theory of total factor productivity. Int. Econ. Rev., 39: 525-551. DOI: $10.2307 / 2527389$

Weizsacker, E., T. Young and R. Oran, 1997. Limits to privatization, privatization organization. World Bank Econ. Rev., 15: 367-391.

Welch, D. and O. Fremond, 2001. The case-by-case approach to privatization: Techniques and examples. Rev. Econ. Stud., 72: 189-221. 